\title{
AUTUMNAL BIRD MIGRATION OBSERVED FROM SHIPS IN THE WESTERN NORTH ATLANTIC OCEAN
}

\author{
By Carol P. McClintock, Timothy C. Williams, and John M. Teal
}

\section{INTRODUCTION}

The western north Atlantic Ocean constitutes a major route for autumnal migrants moving between eastern North America and the Caribbean or South America. Some shorebirds have long been known to use this route (Lincoln, 1939; Hagar, 1966; Palmer, 1968; McNeil and Burton, 1973), and recently Drury and Nisbet (1964) and Nisbet (1970) have stated that the Blackpoll Warbler (Dendroica striata) probably flies over the western Atlantic between New England and South America, although this route was disputed by Murray (1965). Atlantic migrants have been studied with radar installations on the North American coast (Drury and Keith, 1962; Drury and Nisbet, 1964; Richardson, 1972; and Williams et al., 1972 and 1977), on Bermuda (Williams et al., 1972; Ireland and Williams, 1974; Williams et al., 1977), and in the Caribbean (Hilditch et al., 1973; Richardson, 1976; Williams et al., 1977). Southeast departures from the North American coast usually occur at night after the passage of a cold front in the fall (Drury and Nisbet, 1964; Richardson, 1972). Birds moving over the Atlantic must then fly through the cold front that usually becomes stationary between the coast and Bermuda. In doing so, they lose the favorable winds and clear weather which assisted their departure and continue their migration in variable winds and sometimes inclement weather (Williams et al., 1977; Williams and Williams, in press). They then continue their southeast movement over Bermuda to the area of the Sargasso Sea where they encounter the northeast trade winds and eventually pass over the Caribbean islands moving to the southwest (Hilditch et al., 1972; Richardson, 1976; Williams and Williams, in press).

The radar studies reported above show large numbers of birds departing the northeast coast of North America to the southeast. After an interval of about three days, sparser aggregations are seen moving southwest over the Caribbean islands (Williams et al., in press). The radar data do not, at present, allow identification of the birds detected, but reveal only that these birds fly at 30 to $60 \mathrm{~km} / \mathrm{hr}$ (18 to $36 \mathrm{mph}$ ) and are smaller than waterfowl (Williams et al., 1977). Murray (1965, 1976) disputes the hypothesis that these are passerine migrations, pointing out that, although passerines may depart the North American coast on favorable autumnal evenings, many return to the southern sections of that coast in the early morning. Observations from ships at sea would greatly help clarify the identity of those birds detected by radars in the Caribbean and on Bermuda. Hurdis (1897) and Scholander (1955) report sightings of shorebirds and passerines from ships at sea in the vicinity of Bermuda and along the U.S. coast during September and October. The great flocks of shorebirds ("stretching from horizon to 
horizon") reported by Hurdis were assumed to be migrants, but the passerines reported by both authors were considered coastal migrants drifted offshore by winds.

For three to six weeks each fall from 1971 through 1974, we and D. Griffin, R. Larkin, J. Torre-Bueno, and S. Torre-Bueno made observations of bird migration with radars from ships of the Woods Hole Oceanographic Institution cruising the area between New England and the Sargasso Sea. The data obtained with a tracking radar and records of birds seen near the ship in 1971 and 1972 are reported elsewhere (Larkin et al., in press). In 1973 and 1974, we used modified marine search radars and a ceilometer to observe migrants and in 1974 captured and identified as many migrants as possible in an attempt to clarify the identity and behavior of birds over the Atlantic in autumn.

\section{METHODS}

\section{Radars}

The radars we used were modified marine radars that followed many birds simultaneously in two dimensions but did not give information on their altitude. The radars detected birds at $<2 \mathrm{~km}$ range, and it is improbable that they detected birds at $>500 \mathrm{~m}$ altitude.

In 1973, we used a Raytheon 1640 radar: $3 \mathrm{~cm}$ wavelength, $40 \mathrm{~kW}$, vertical beamwidth $22^{\circ}$, horizontal beamwidth $0.6^{\circ}$. In 1974 , we used a Decca 838: $3 \mathrm{~cm}$ wavelength, $75 \mathrm{~kW}$ peak power, vertical beamwidth $15^{\circ}$, horizontal beamwidth $0.78^{\circ}$. The two marine radars were modified by having their antennas tilted upwards at $7^{\circ}$ and $30^{\circ}$ respectively.

The radar observations reported in this paper were made from 0000 GMT 29 Sept. to 1500 GMT 5 Oct. 1973, and 0000 GMT 2 Oct. to 2100 GMT 21 Oct. 1974. During periods of heavy seas and storms, returns from birds could not be detected on our radars. Such conditions prevented our obtaining data from 0500 to 1900 GMT 1 Oct. 1973, 1000 GMT 2 Oct. to 0500 GMT 3 Oct. 1973, and after 2000 GMT 20 Oct. 1974. We were also unable to obtain data while the ship was in port in Bermuda 0000 GMT 8 Oct. to 2000 GMT 11 Oct. 1974.

\section{Meteorological Data}

Observations of weather conditions were recorded every four hours or more frequently when a rapid change in the weather occurred. Direction and speed of the wind with corrections for the ship velocity were obtained from the bridge wind indicators located $15 \mathrm{~m}$ above the sea surface. Wind velocity was monitored continuously and recorded every four hours.

Synoptic weather patterns were obtained from National Meteorological Center Northern Hemisphere surface charts issued every six hours.

\section{Analysis of Radar Data}

Data were obtained either directly from the radar screen by tracing the movement of single birds or tight flocks of birds (Williams et al., 
1977) on plotting sheets, by time exposures of the radar screen in which echoes from birds produced a streak in the photograph, or by time lapse $8 \mathrm{~mm}$ cine film in which one frame of film was exposed for each revolution of the radar antenna. The apparent direction and speed of each detected bird were then corrected for the movement of the ship giving us the movement of the birds relative to the surface of the earth $\left(\mathrm{V}_{\mathrm{g}}\right)$. By using vector addition of the velocity of the wind $\left(V_{w}\right)$ we obtained from $V_{g}$ the movement of the birds relative to the air mass $\left(V_{a}\right)$. $\mathrm{V}_{\mathrm{a}}$ indicates the directional orientation of the birds and their flight speed as if measured in still air. In aviation terminology $V_{a}=$ airspeed and heading; $V_{\mathrm{g}}=$ groundspeed and track; $\mathrm{V}_{\mathrm{w}}=$ windspeed and direction.

The density of bird migration within the $2 \mathrm{~km}$ circle was scored on a four point scale: no movement detected, light movement ( $15 \mathrm{birds} /$ $\mathrm{hr}$ ), moderate movement (20 to $50 \mathrm{birds} / \mathrm{hr}$ ) and heavy movement of birds (50 to $150 \mathrm{birds} / \mathrm{hr}$ ).

\section{Capture and Identification}

Visual observations were made from 14 Sept. through 6 Oct. 1973 and 26 Sept. through 22 Oct. 1974.

In 1974, tape recordings (obtained from the Cornell Laboratory of Ornithology) of the vocalizations of Setophaga ruticilla, Junco hyemalis, Dendroica tigrina, Riparia riparia, and Otus asio were played through a loudspeaker system on the upper deck of the ship to attract birds. In the same area we placed three baited drop door traps: one baited with dripping water, one with seeds and grain, and one with meal worms. A caged canary was also placed in this area in mild weather. The passerine songs were chosen because of sightings of these same species on previous cruises. The owl vocalization was selected because it often attracts passerines.

Attempts to record bird calls were unsuccessful due to noise from the ship's machinery.

In 1974 , all decks were checked each day at sunrise, noon, and sunset for birds. In addition the first author spent all daylight hours not required for collecting radar or weather data watching for birds with $7 \times$ 50 or $10 \times 50$ binoculars.

All birds that were found dead on the ship were retained for later examination. Several hand nets were placed at intervals around the ship to aid in capture of flying birds. Although the discharge of firearms was not permitted on the ship, the first author was able to collect three specimens using an improvised slingshot with grapes as ammunition.

Captured birds were immediately killed by thoracic pressure and frozen. Each bird was categorized according to sex, age, weight, fat, keel, external and internal injuries, stomach contents, and internal parasites. Prepared study skins of most of the specimens are in the bird and mammal collection of the Cornell University Museum.

In 1974, a 20-W fluorescent light in a waterproof housing was used to attract insects; this was placed on the top deck of the ship facing the 
bow. Unfortunately it appeared too smilar to the ship's running lights and had to be removed after two nights.

The ceilometer technique described by Gauthreaux (1970) was used to observe nocturnal migrants in 1973. A $200-\mathrm{W}$ ceilometer bulb was mounted in a housing set on the deck so the beam pointed upwards from the deck. The light was powered by a $6-\mathrm{V}$ battery which provided adequate illumination for $2 \frac{1}{2} 2$ hours. Observers lay supine on the deck and observed along the light beam with hand-held $10 \times 50$ binoculars. Observation was made difficult by the vibration and rolling of the ship which prevented mounting the binoculars on a tripod.

RESULTS

\section{Radar Observations}

Bird migration observed at sea both visually and with radars was intermittent. Typically a period of no migratory activity followed, often suddenly, a period of 4 to 12 hours when many birds were seen around the ship or on radar. During migratory periods birds usually exhibited consistent migratory behavior with the next period of activity showing different airspeeds, direction, or dispersions of air headings.

Table 1 gives the average $V_{g}, V_{a}$ and $V_{w}$ for all periods of migratory activity (scored moderate or heavy). Direction is given as the vector mean direction, speed as the average recorded speed. The angular deviation (see Batschlet, 1965) is given for $\mathrm{V}_{\mathrm{g}}$ as a measure of dispersion. If the angular deviaiton of $\mathrm{V}_{\mathrm{a}}$ exceeded $60^{\circ}$ we considered the average direction of $\mathrm{V}_{\mathrm{a}}$ of little value in analysis (indicated SC, for scattered heading, in Table 1).

During our observations, sunset occurred at about 2300 GMT and sunrise at about 1000 GMT.

Three types of movement were observed on radar. In the first type the great majority of the birds observed were heading to the south or southeast, and only moderate variability occured in observed $\mathrm{V}_{\mathrm{g}}$ direction of flight (average ang. dev. $=34^{\circ}$ ). These groups of birds appeared to be well-oriented migrants, and if they persisted in their observed behavior would probably have reached the Caribbean or South America. The second type of movement we observed consisted of groups of birds with scattered air headings ( $\mathrm{SC}$ in Table 1). If, as a group, they made any significant net progress, it was due to drift by the wind (see 5 Oct. 1974). The third type of movement was seen on 19 Oct. 1974. As a tropical depression advanced on the ship from the southwest, we detected many birds heading $\left(\mathrm{V}_{\mathrm{a}}\right)$ to the west (toward the North American coast) but making little progress against the rising winds which reached speeds of $110 \mathrm{~km} / \mathrm{hr}$ as the storm passed over the ship. Observations of bird movement during the height of the storm were not possible due to radar return from the heavy seas.

The accuracy of calculated airspeeds in Table 1 is dependent upon the measured winds as well as $\mathrm{V}_{\mathrm{g}}$. We compared all the measured wind 


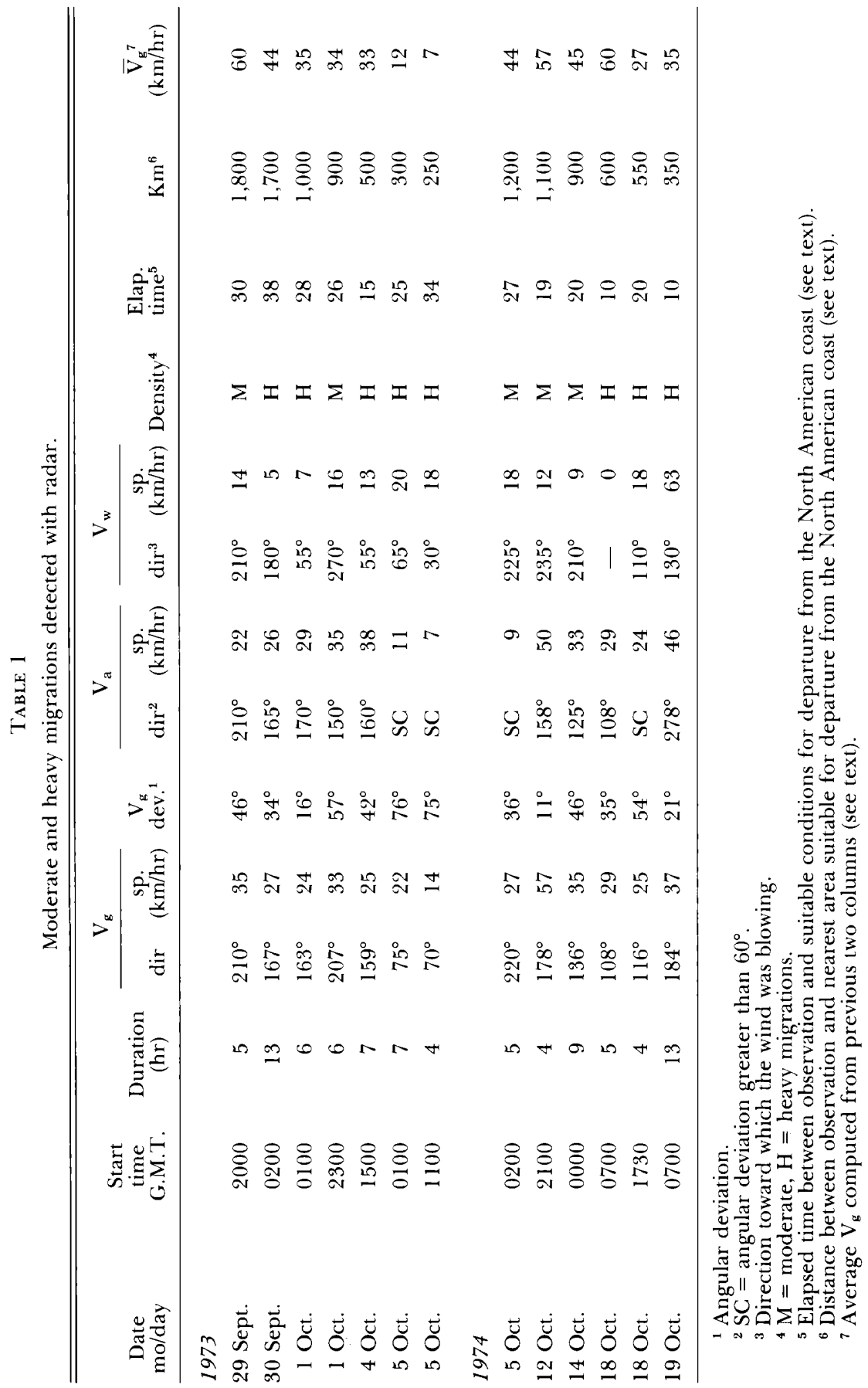


values with data taken from surface weather maps of the area (other ships and geostrophic winds) and found that data taken from the ship were consistent with all other wind data available to us. Thus, although an undetermined error is in the calculation of $\mathrm{V}_{\mathrm{a}}$, it appears unlikely to have been consistently under- or over-estimated.

With the exception of 12 Oct. 1974, the calculated average airspeeds for the nine groups of well-oriented migrants ranged from 22 to $38 \mathrm{~km} /$ hr (average $=30$ ). These values agree well with the values calculated by Pennycuick (1969) for small passerine migrants. On the basis of body weight alone the smaller shorebirds should overlap the passerines in this range. The very few accurate measurements of $V_{a}$ for small shorebirds suggest, however, that they fly considerably faster (Tucker and Schmidt-Koenig, 1971: Sandpipers [Calidris spp.] $=68 \mathrm{~km} / \mathrm{hr}$ ). In the last three columns of Table 1 we make a rough estimate of the time between the birds' departure from the North American coast and their arrival within range of our radar. To do this we determined from weather maps the most recent occurrence of conditions favorable for offshore departures from the North American coast using the criteria reported by Drury and Keith (1962), Drury and Nisbet (1964), and Richardson (1972): winds from the north or northwest, clearing skies, the passage of a cold front and nightfall. (When the ship was $>1,000 \mathrm{~km}$ from the coast we assumed that the birds must have departed at least 12 hours before our observations.) The elapsed times calculated in this way give the minimum time available for passage; in almost all cases, birds could also have taken off 24 hours earlier. Distances to land given in Table 1 are the minimum distances to those portions of the North American coast offering the favorable conditions mentioned above. The average $\mathrm{V}_{\mathrm{g}}$ calculated from these values reflects the favorable winds birds enjoyed during the first part of their flight as well as the birds' airspeed. In this way it is interesting to note that all but two of the values are below $60 \mathrm{~km} / \mathrm{hr}$, again suggesting that we were observing relatively slowly flying birds.

On four occasions we observed radar echoes with scattered air headings $\left(\mathrm{V}_{\mathrm{a}}\right)$ and in most cases remarkably low airspeeds (7 to $24 \mathrm{~km} / \mathrm{hr}$ ). The aerodynamic calculations of Pennycuick (1969) indicate that migrant insects would be capable of these airspeeds and Schaefer (1976) has detected migratory insects with a radar similar to those we used. We, however, believe that these echoes were due to birds for several reasons: (1) the echoes were sharp, coherent echoes detected at the same ranges as the faster flying, well-directed bird echoes; (2) similar, slowly moving echoes were detected with a tracking radar on previous cruises which Larkin et al. (in press) concluded were due to birds on the basis of radar signature and other flight characteristics; (3) despite our efforts to attract insects to the ship with lights and the large number of work lights on the ship, few insects were seen at sea (Table 2); (4) although bats were seen at sea, these also were rare.

The calculations of probable departure time and average $V_{g}$ for these 


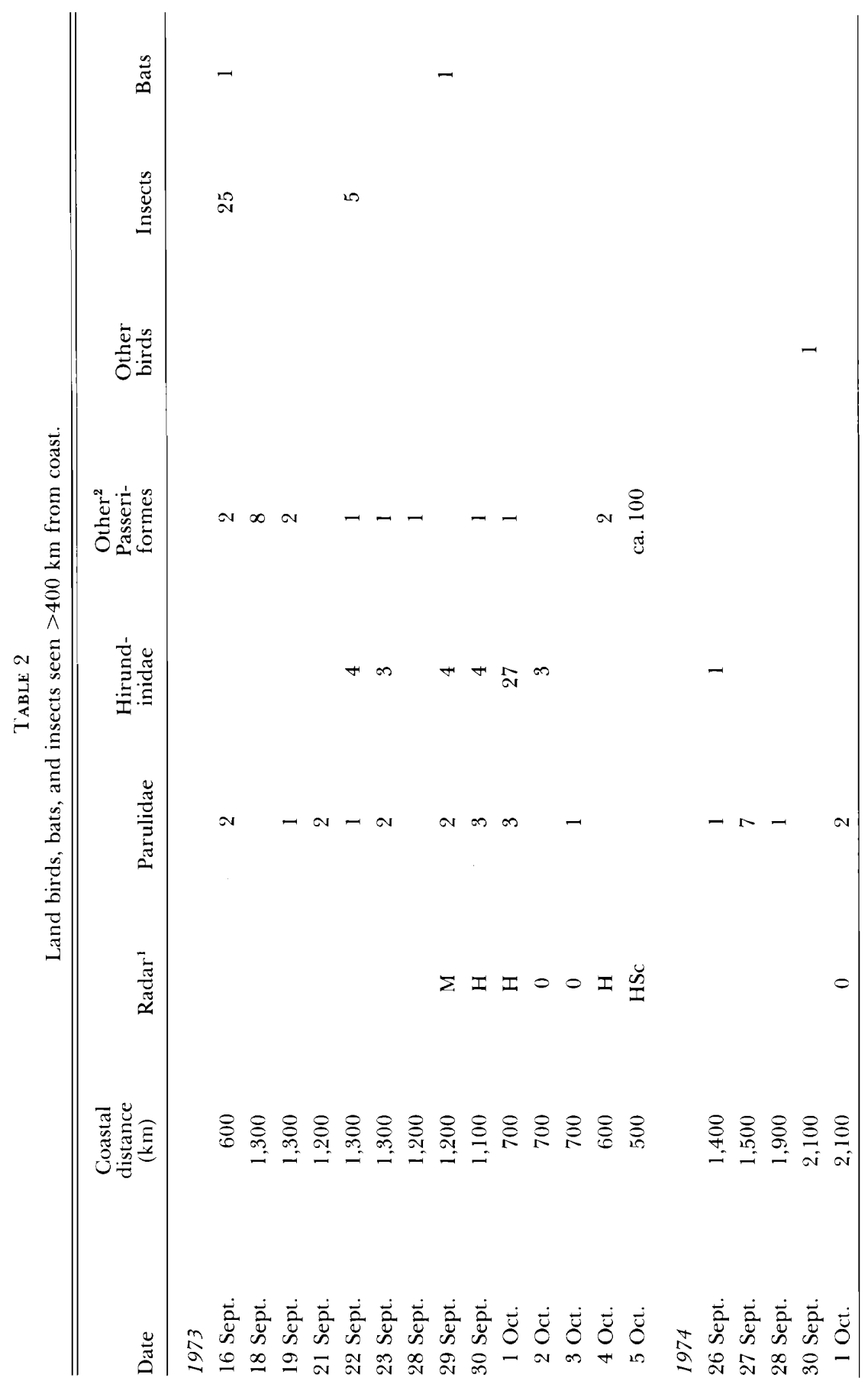




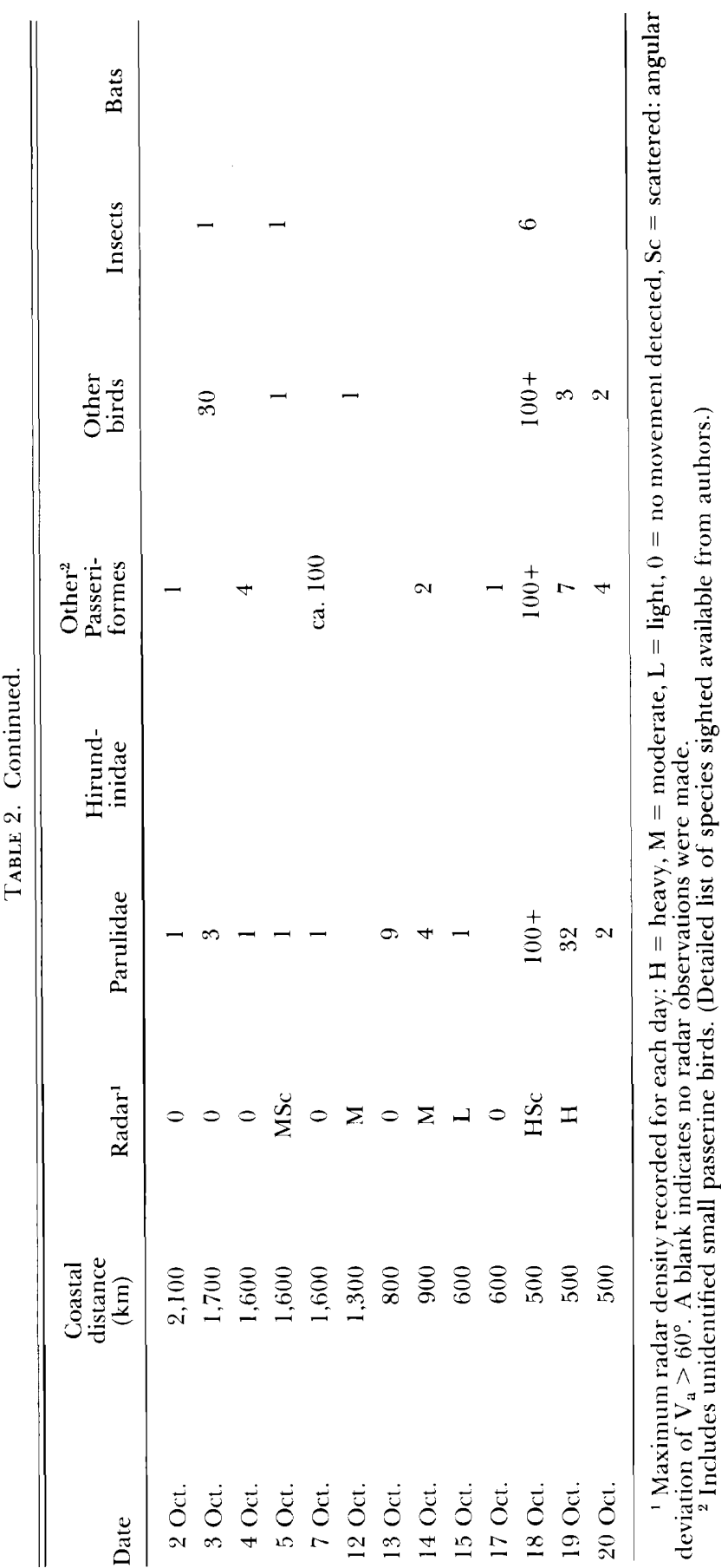




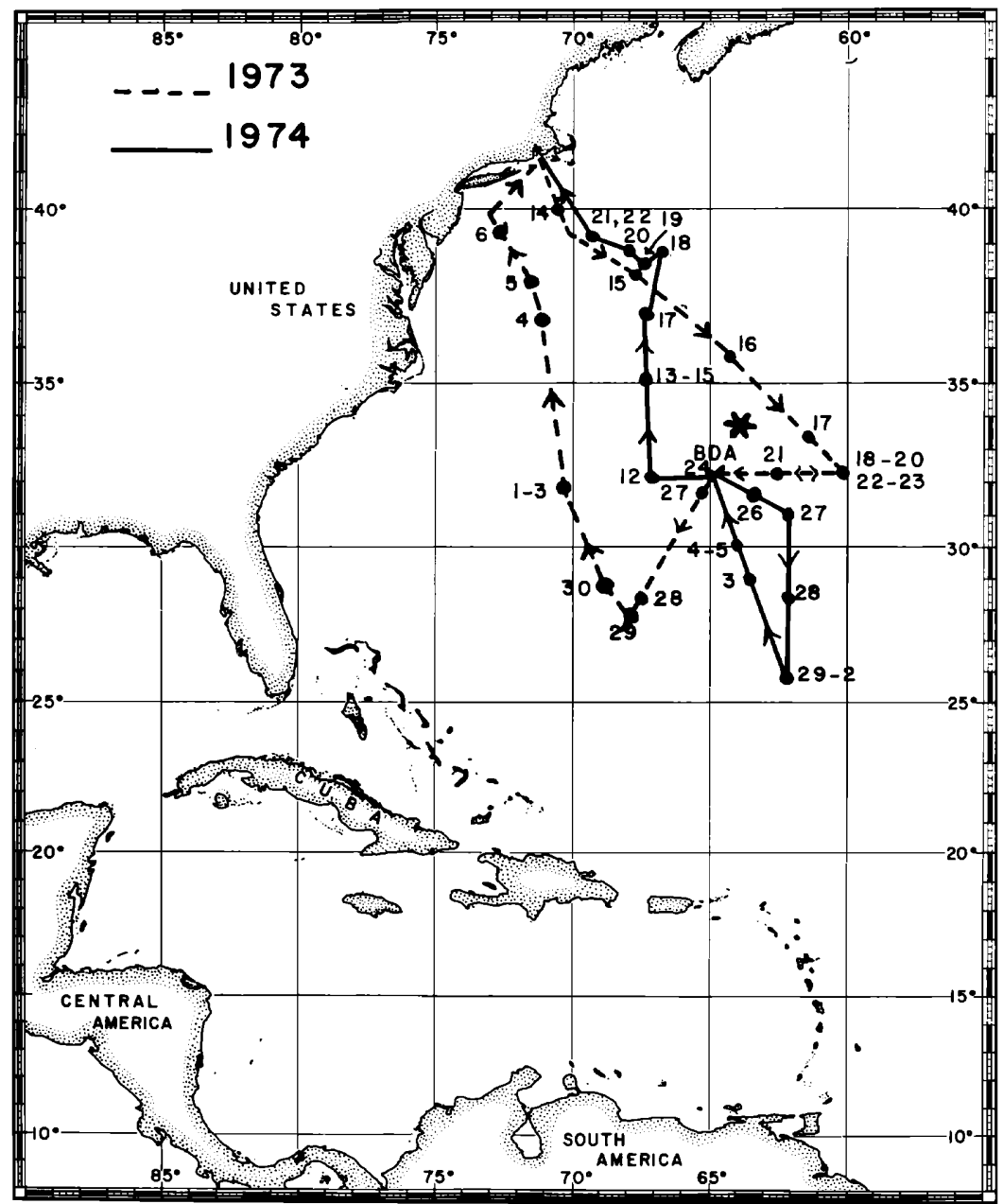

Figure 1. Route of ships for observations of bird migration made in 1973 and 1974.

Both cruises were made from mid-September to mid-October. Dots give position of ship at noon. Numbers give day of the month. Asterisk shows location of ship when three migrant birds, included in Table 3, were collected prior to our observations.

birds in Table 1 indicate that either the birds moved very slowly away from the coast (5 Oct. 1973) or that they departed at more normal flight speeds and then changed to the disoriented behavior we observed (5 and 18 Oct. 1974). The tracks of these birds on the radar screen were not demonstrably more curving than were those of apparently successful migrants; for both groups most tracks were straight for the distances of 0.25 to $0.5 \mathrm{~km}$ that we could detect the birds. 


\section{Visual Observations}

Figure 1 shows the position of the ship at noon for 1973 and 1974 cruises. Table 2 lists the number of land birds, bats, and insects seen from the ship on these cruises, the approximate minimum distance to the northeast coast of North America and the maximum density of migration detected by radar on those days. A similar table will be found in Larkin et al. (in press) for 1971 and 1972.

Land birds, especially warblers and other passerines, were seen in all areas of the western north Atlantic covered on our cruises although the greatest concentrations were detected within $600 \mathrm{~km}$ of the coast. The largest numbers of birds (5 Oct. 1973 and 18 Oct. 1974) were seen behind stationary fronts. However, on several days we saw many birds well to the south and east of a frontal system often far from land (see the lower right of Figure 1, 30 Sept. 1973, 1 Oct. 1973, 27 Sept. 1974 and 7 Oct. 1974). It therefore appears unlikely that all passerines seen from the ships were drifted by strong offshore winds.

A comparison of the maximum density of birds detected by radar and the number of birds seen from the ship on the same days reveals major discrepancies (4 Oct. 1973; 3, 5 and 12 Oct. 1974). The Spearman-Rank Correlation Coefficient of a number of birds detected by radar vs. those recorded visually is $0.49(P<.01)$, indicating a significant but weak association. This suggests that the two techniques may, to some extent, be observing different aspects of migratory behavior. A similar conclusion was reached by Nisbet and Drury (1969) in comparing the results of mist netting and watching birds pass the disc of the moon at night.

\section{Captured Specimens}

Table 3 lists the 25 species of birds captured on the 1973 and 1974 cruises, capture dates, number of specimens, and weight and fat ranges. A more detailed data list suitable for computer input is available from the second author.

In 1974, examinations were performed on all captured specimens. This sample consisted of 31 males, 19 females, and 6 birds of unknown sex. There were 7 adults and 49 immatures. These data are insufficient to determine age or sex ratios by species.

The stomachs of most birds were empty. Some had debris, paint chips and sand, and a few had seeds and undigested insect parts. All these items could have been obtained on board ship.

Most of the birds found dead had skull hemorrhages and probably died after flying into ship structures.

A gross examination of the body cavity revealed no internal parasites, suggesting that these birds departed the North American coast in good health. Two external Hippoboscids were found, one on a Dark-eyed Junco, and one on a White-throated Sparrow.

Of the 39 birds trapped in the meal worm trap, netted or hand captured, 11 had fat (fat class 2 or 3, Table 3). Of the 16 birds either found 
TABLE 3

Captured specimens.

\begin{tabular}{|c|c|c|c|c|c|}
\hline & \multicolumn{2}{|c|}{ Capture date } & \multirow{2}{*}{$\begin{array}{c}\text { Num- } \\
\text { ber }\end{array}$} & \multirow{2}{*}{$\begin{array}{l}\text { Weight } \\
\text { range } \\
\text { (g) }\end{array}$} & \multirow{2}{*}{$\begin{array}{l}\text { Fat }^{1} \\
\text { range }\end{array}$} \\
\hline & Sept. & Oct. & & & \\
\hline \multicolumn{6}{|l|}{1973} \\
\hline Sora (Porzana carolina) & 14 & & 1 & - & 0 \\
\hline $\begin{array}{l}\text { Pine Warbler } \\
\text { (Dendroica pinus) }\end{array}$ & & 1 & 1 & - & 2 \\
\hline $\begin{array}{l}\text { American Redstart } \\
\text { (Setophaga ruticilla) }\end{array}$ & 21 & & 1 & - & 0 \\
\hline \multicolumn{6}{|l|}{1974} \\
\hline $\begin{array}{l}\text { Common Nighthawk } \\
\text { (Chordeiles minor) }\end{array}$ & & 1 & 1 & 40.4 & 0 \\
\hline $\begin{array}{l}\text { Ruby-crowned Kinglet } \\
\text { (Regulus calendula) }\end{array}$ & & 19 & 1 & 5.3 & 1 \\
\hline $\begin{array}{l}\text { Black-and-white Warbler } \\
\text { (Mniotilta varia) }\end{array}$ & 10 & & 1 & 6.4 & 0 \\
\hline $\begin{array}{l}\text { Tennessee Warbler } \\
\text { (Vermivora peregrina) }\end{array}$ & & 18 & 1 & 8.5 & 2 \\
\hline $\begin{array}{l}\text { Nashville Warbler } \\
\quad \text { (Vermivora ruficapilla) }\end{array}$ & & 18 & 1 & 8.2 & 3 \\
\hline $\begin{array}{l}\text { Cape May Warbler } \\
\text { (Dendroica tigrina) }\end{array}$ & 16 & 2,19 & 4 & $6.8-8.2$ & $0-1$ \\
\hline $\begin{array}{l}\text { Black-throated Blue Warbler } \\
\text { (Dendroica caerulescens) }\end{array}$ & & 19 & 2 & $7.9-11.7$ & $1-3$ \\
\hline $\begin{array}{l}\text { Yellow-rumped Warbler } \\
\text { (Dendroica coronata) }\end{array}$ & & $5,19,22$ & 7 & $8.5-10.6$ & $0-1$ \\
\hline $\begin{array}{l}\text { Black-throated Green Warbler } \\
\text { (Dendroica virens) }\end{array}$ & & 19 & 2 & $7.3-8.0$ & $0-2$ \\
\hline $\begin{array}{l}\text { Blackburnian Warbler } \\
\text { (Dendroica fusca) }\end{array}$ & & 18 & 1 & 11.4 & 3 \\
\hline $\begin{array}{l}\text { Bay-breasted Warbler } \\
\text { (Dendroica castanea) }\end{array}$ & & 19 & 1 & 17.2 & 3 \\
\hline $\begin{array}{l}\text { Blackpoll Warbler } \\
\text { (Dendroica striata) }\end{array}$ & & 18,19 & 4 & $10.6-17.3$ & 3 \\
\hline $\begin{array}{l}\text { Pine Warbler } \\
\text { (Dendroica pinus) }\end{array}$ & & 19 & 1 & 12.1 & 3 \\
\hline $\begin{array}{l}\text { Palm Warbler } \\
\text { (Dendroica palmarum) }\end{array}$ & & $13,14,18,19$ & 14 & $7.3-10.0$ & $0-2$ \\
\hline $\begin{array}{l}\text { Ovenbird } \\
\quad \text { (Seiurus aurocapillus) }\end{array}$ & & 19 & 1 & 26.3 & 3 \\
\hline $\begin{array}{l}\text { Common Yellowthroat } \\
\text { (Geothlypis trichas) }\end{array}$ & & 19 & 1 & 7.3 & 1 \\
\hline $\begin{array}{l}\text { American Redstart } \\
\text { (Setophaga ruticilla) }\end{array}$ & 27 & & 2 & 6.3 & 0 \\
\hline $\begin{array}{l}\text { Bobolink } \\
\text { (Dolichonyx oryzivorus) }\end{array}$ & & 19 & 1 & 49.3 & 3 \\
\hline $\begin{array}{l}\text { Red-winged Blackbird } \\
\text { (Agelaius phoeniceus) }\end{array}$ & & 19 & 1 & 35.5 & 0 \\
\hline
\end{tabular}


TABle 3. Continued.

\begin{tabular}{|c|c|c|c|c|c|}
\hline & \multicolumn{2}{|c|}{ Capture Date } & \multirow{2}{*}{$\underset{\text { ber }}{\text { Num- }}$} & \multirow{2}{*}{$\begin{array}{l}\text { Weight } \\
\text { Range } \\
\text { (g) }\end{array}$} & \multirow{2}{*}{$\begin{array}{c}\text { Fat }^{1} \\
\text { Range }\end{array}$} \\
\hline & Sept. & Oct. & & & \\
\hline $\begin{array}{l}\text { Grasshopper Sparrow } \\
\quad \text { (Ammodramus savannarum) }\end{array}$ & & 19 & 1 & 14.8 & 1 \\
\hline $\begin{array}{l}\text { Dark-eyed Junco } \\
\text { (Junco hyemalis) }\end{array}$ & & 17 & 3 & $13.5-17.6$ & $1-3$ \\
\hline $\begin{array}{l}\text { Chipping Sparrow } \\
\text { (Spizella passerina) }\end{array}$ & & 18 & 1 & 10.4 & 1 \\
\hline $\begin{array}{l}\text { White-throated Sparrow } \\
\text { (Zonotrichia albicollis) }\end{array}$ & & 21,22 & 3 & $20.1-21.5$ & $0-2$ \\
\hline $\begin{array}{l}\text { Snow Bunting } \\
\quad \text { (Plectrophenax nivalis) }\end{array}$ & & 22 & 1 & 19.8 & 0 \\
\hline
\end{tabular}

${ }^{1}$ Fat classification: $0=$ no fat in furcula or abdomen; $1=$ spots to $1 / 2$ filled furcula and thin strips of abdominal fat; $2=1 / 2$ full to flush furcula and thin strips of fat to flush fat in abdomen; 3 = full, bulging furcula and flush to bulging abdomen.

Birds in 0-1 classes, "no fat," would have been physically unable to continue migration for long. Birds in 2-3 classes, "fat," could have continued migrating for some time.

dead or shot with the slingshot, 9 were moderately to excessively fat. (The cause of death of one bird was uncertain.) A Chi-square test using pooled fat classes $(0-1$ and $2-3)$ vs. capture methods indicated that the capture methods were not significantly associated with fat or lean birds $\left(\chi^{2}=8.4 ; \mathrm{df}=5 ; P>.05\right)$.

Of those bird species captured and examined, the following species had one or more fat individuals: Blackpoll, Nashville, Blackburnian, Pine, Bay-breasted and Black-throated Blue warblers, Ovenbird, and Bobolink.

\section{Behavior}

The behavior of passerines seen from the ship fell into two categories: birds passing by the ships and birds attracted to the ships. With the exception of 7 Oct. and 18 Oct. 1974 when large numbers of warblers flew over the ship moving south, we rarely saw more than one or two passerines per day flying past the ship. The great majority of our observations were of birds attracted to the ship because these stayed in view a much longer time.

Birds attracted to the ship often flew in pairs and circled the ship for an hour or more, alighted on the ship itself or flew into the laboratories or other rooms open to the outside. Many of these birds showed signs of exhaustion or disorientation; they could be approached easily; they walked unsteadily or flew into obstacles. On five occasions passerines fell or descended to the surface of the sea and almost immediately flew up again; on two occasions drowning birds floated past the ship. Of the attractive devices used, the meal worms, the caged bird, and the re- 
corded songs of birds were most successful. South of Bermuda in 1974, the recorded songs caused almost all birds seen near the ship to investigate the area of the loudspeaker. This occurred at all times of day. North of Bermuda, although many birds were seen, they were not attracted to the recorded songs. Birds were not attracted by water or seeds.

A ceilometer was used for $21 / 2$ hours per night starting at about 2200 local time from 17 Sept. 1973 to 2 Oct. 1973. The greatest number of birds seen per night was three (moving to the SW, S, and SE) on 30 Sept. 1973, the only night with heavy southward migration on radar during that period. The very low numbers of birds seen compared to similar observations on land may have been due to low density of birds aloft, deviation of migrants away from the immediate area of the ship, or to the difficulty of ceilometer observation from a ship (see Methods).

On 28 Sept. 1973, a small passerine, apparently catching insects, was seen hovering near but not in the beam of the ceilometer; this was confirmed the following day when a Palm Warbler was seen flying with the remains of a moth in its beak. The autopsies of captured birds revealed, however, that such insect-catching at sea must be rare.

On four occasions (12 Oct. 1971, see Teal and Teal, 1975, and 7, 17 and 18 Oct. 1974) a rain squall passed over the ship at night and large numbers of passerines were heard calling as they moved over the ship and were seen in the ship's lights or a ceilometer beam. In each case when the overcast cleared sufficiently to reveal a few stars, the birds suddenly vanished from sight and their calls could no longer be heard. A similar instance was recorded at night on radar on 12 Oct. 1974 when many birds were seen just after a rain shower and disappeared when the sky cleared partially.

In addition to passerines, we saw large numbers of shearwaters on 19 and 20 Oct. 1974, and on 2 Oct. 1974, we saw two flocks of shorebirds (one being ca. 30 phalaropes) flying low over the water to the southeast. On 5 and 6 Oct. 1974, a Merlin (Falco columbarius) alighted on the ship's masts several times a day. During its low flights over the water, it attempted to catch flying fish at least twice.

\section{DISCUSSION}

Visual observations revealed passerines, especially warblers, in all areas of the Atlantic covered in this study. Radar revealed large numbers of birds with airspeeds of 20 to $40 \mathrm{~km} / \mathrm{hr}$ directing their flight to the south and southeast as far as 2,100 km from the North American coast.

As Murray (1965 and 1976) has emphasized, the presence of large numbers of passerines at sea does not necessarily indicate a migration route over that area. He suggests these could be birds drifted from a migration route along the coast by strong northwest winds. We do not believe this is the case; passerines were seen far from the coast under wind conditions that required active southeast flight. Radar observations revealed such flight behavior at speeds within the range of expected 
migratory flight speeds of passerines. Although it is possible that all such radar echoes were due to small shorebirds, we rarely saw shorebirds during these cruises (although small shorebirds were regularly reported from ships in these waters during the late 1800 's, Hurdis, 1897).

The rather weak correlation of density of birds seen visually and on the radar indicates that the two methods may not be fully equivalent. The preponderance of emaciated and immature birds, especially southeast of Bermuda, suggests that these birds were attracted to the ship as a resting place, while birds in good condition passed over the ship and were detected by radar. Birds in good condition tended to be seen during periods of poor weather such as those reported in Table 3 on 18 and 19 Oct. 1974. Such observations support the hypothesis that there are indeed passerines in good condition over the Atlantic but that these birds do not usually land on ships.

The visual observations reveal a strong tendency for passerines to fly in pairs or flocks. This might be due only to the well known flocking of migrant passerines during the day (Gauthreaux, 1970), but the sudden appearance and disappearance of great numbers of birds around the ships at night suggest that the birds might also group together at night.

The three instances of apparent disorientation under overcast and rain at night are similar to those reported by Drury and Keith (1962) near the coast and indicate that celestial orientation may be important for these birds.

Nisbet (1970) deduced, by analyzing the occurrence of Blackpoll Warblers at tower and lighthouse kills along the North American coast, that D. striata makes a direct crossing of the Atlantic from New England and the Canadian Maritimes to South America. Of the probable Atlantic migrants listed in Drury and Keith (1962), we frequently observed Cape May Warblers, Yellow-rumped Warblers, and American Redstarts south of Bermuda. Thus, several species of passerines are regularly seen in the western Atlantic, some individuals of which have sufficient fat to make long flights without stopping.

\section{SUMMARY}

Observations from ships using radar and direct visual observations confirm that the western North Atlantic is a site of major passerine migrations during the latter part of September and most of October.

Radar observations revealed several types of migratory patterns, including well directed movements of birds to the south, poorly oriented birds unlikely to survive, and birds attempting to return to land or avoid an approaching tropical storm.

Visual observation revealed substantial numbers of passerines, especially warblers and swallows, as far as $2,100 \mathrm{~km}$ from the North American coast. Examination of captured specimens revealed fat individuals of several passerine species, primarily warblers. However, a majority of the specimens were immature and emaciated. 
During periods of fair weather only birds with little fat or immature birds tended to alight on the ship although radar often revealed large numbers of birds passing overhead. Birds in good condition tended to be seen only during storms. Such observations support the hypothesis that there are indeed passerines in good condition over the Atlantic but that these birds do not usually land on ships.

\section{ACKNOWLEDGMENTS}

We are indebted to D. Griffin, R. Larkin, J. Torre-Bueno, and S. Torre-Bueno for permission to use data collected by them during 1971 and 1972. The officers, seamen, and shop staff of the Woods Hole Oceanographic Institution frequently went out of their way to assist us in obtaining data and setting up or repairing equipment. P. Gold assisted in preparing the sound systems for recorded bird calls. R. Bauer and D. Riker aided in identification, autopsies, and study skin preparations.

This research was supported by Grants GB 13246 and GB 43252 from the National Science Foundation. This paper is contribution No. 3994 of the Woods Hole Oceanographic Institution.

The Library of Natural Sound, Laboratory of Ornithology, Cornell University provided tape recordings of several bird songs.

R. Larkin, C. C. McClintock, B. Murray, and J. Williams read the manuscript and made several helpful suggestions. J. Williams also assisted with nomenclature.

\section{LITERATURE CITED}

BAtschlet, E. 1965. Statistical methods of analysis of problems in animal orientation and certain biological rhythms. AIBS monograph, Washington, D.C. A.I.B.S.

Drury, W. H., AND J. A. KeIth. 1962. Radar studies of songbird migration in coastal New England. Ibis, 104: 449-489.

Drury, W. H., and I. C. T. Nisbet. 1964. Radar studies of orientation of songbird migrants in southeastern New England. Bird-Banding, 35: 69-119.

GaUthreaux, S. A., JR. 1970. Weather radar quantification of bird migration. BioScience, 20: $17-20$.

HAGAR, J. A. 1966. Nesting of the Hudsonian Godwit at Churchill, Manitoba. Living Bird, 5: $1-43$.

Hilditch, C. D. M., T. C. Williams, and I. C. T. Nisbet. 1973. Autumnal bird migration over Antigua., Bird-Banding, 44: 171-179.

Hurdis, J. L. 1897. Rough notes and memoranda relating to the Natural History of the Bermudas by the late John L. Hurdis edited by his daughter H. J. Hurdis. London, R. H. Porter.

Ireland, L. C., AND T. C. Williams. 1974. Radar observations of bird migration over Bermuda. Proc. Conf. on the Biol. Aspects of the Bird/Aircraft Collision Problem. S. Gauthreaux, ed. Arlington, Va., U.S.A.F. Office of Scientific Research.

Larkin, R. P., J. Torre-Bueno, D. R. Griffin, and J. M. Teal. Radar observations of bird migration over the western North Atlantic Ocean. Behav. Ecol. Sociobiol: in press.

Lincolv, F. C. 1939. The Migration of American Birds. New York, Doubleday, Doran and Co., Inc.

MCNeIL, R., AND J. Burton. 1973. Dispersal of some southbound migrating North American shorebirds away from the Magdalen Islands, Gulf of St. Lawrence and Sable Island, Nova Scotia. Carib. J. Sci., 13: 257-278.

Murray, B. G. 1965. On the autumn migration of the Blackpoll Warbler. Wilson. Bull., 77: $122-133$. 
1976. The return to the mainland of some nocturnal passerine migrants over the sea. Bird-Banding, 47: 345-359.

Nisbet, I. C. T. 1970. Autumn migration of the Blackpoll Warbler: evidence for long flight provided by regional survey. Bird-Banding, 41: 207-240.

Nisbet, I. C. T., AND W. H. DruRy. 1969. A migration wave observed by moon watching and at banding stations. Bird-Banding, 40: 243-254.

Palmer, R. S. 1968. Species accounts. In: The Shorebirds of North America, G. D. Stout, ed. New York, The Viking Press.

Pennycuick, C. J. 1969. The mechanics of bird migration. Ibis, 111: 525-556.

Richardson, W. J. 1972. Autumn migration and weather in eastern Canada; a radar study. Am. Birds, 26: 10-17.

- 1976. Autumn migration over Puerto Rico and the western Atlantic: a radar study. Ibis, 118: 309-332.

Schaefer, G. W. 1976. Radar observations of insect flight. In: Insect Flight, R. C. Rainey, ed. Symp. Royal Ent. Soc. London, No. 7; Oxford, Blackwell.

Scholander, S. I. 1955. Land birds over the western North Atlantic. Auk, 72: 225-239.

Teal, J. M., and M. Teal. 1975. The Sargasso Sea. Boston, Little, Brown.

Tucker, V. A., And K. Schmidt-Koenig. 1971. Flight speeds of birds in relation to energetics and wind directions. Auk, 88: 97-107.

Williams, T. C., and J. M. Williams. The orientation of transatlantic migrants. Proc. a Symp. Animal Migration, Orientation and Homing, K. Schmidt-Koenig and W. Keeton, eds. Heidelberg, Springer Verlag (in press).

Williams, T. C., J. M. Williams, J. M. Teal, and J. W. Kanwisher. 1972. Tracking radar studies of bird migration. In: Animal Orientation and Navigation: a Symposium. NASA SP 262. Washington, D.C. U.S. Govt. Printing Office.

Williams, T. C., J. M. Williams, L. C. Ireland, and J. M. Teal. 1977. Autumnal bird migration over the western North Atlantic Ocean. Am. Birds, 31: 251-267.

Williams, T. C., J. M. Williams, L. C. Ireland, and J. M. Teal. Flight time for autumnal migrants between North America and the Caribbean estimated by radar. Am. Birds (in press).

C. P. M. 196 Irish Settlement Road, Freeville, NY 13068; T. C. W. Department of Biology, Swarthmore College, Swarthmore, PA 19081; J. M. T. Woods Hole Oceanographic Institution, Woods Hole, MA 02543. Received 21 Oct. 1977 , accepted 15 June 1978. 